\title{
Elżbieta Mazur*
}

iD https://orcid.org/0000-0001-6986-9386

\section{Literackie podróże, czyli \\ o przestrzeni i miejscu w literaturze polskiej przełomu XX i XXI wieku (na przykładzie poezji Adama Zagajewskiego i prozy Andrzeja Stasiuka)}

\section{Uwagi wstępne}

W kształceniu polonistycznym szkół średnich powinno się znaleźć miejsce i czas na omawianie literatury współczesnej okresu okołoprzełomowego oraz twórczości ostatnich dekad. Wychodząc naprzeciw zainteresowaniom czytelniczym młodzieży, warto więcej uwagi poświęcić zjawiskom łączonym z 1989 rokiem, jako czasem przynoszącym zmiany nie tylko w życiu politycznym i społecznym, lecz także w literaturze. Trzeba również uwzględnić twórczość najnowszą, dość często odwołującą się do zjawisk in statu nascendi odzwierciedlających problemy XXI wieku.

Przedmiotem rozważań będą zatem kwestie tożsamości, poetyka miejsca i migracji, a także doświadczenia podróży w poezji Adama Zagajewskiego z tomów Jechać do Lwowa (1985) i Ziemia ognista (1994) ${ }^{1}$ oraz w prozie Andrzeja Stasiuka (na przykładzie opowiadania Miejsce z tomu Opowieści galicyjskie (1995) i powieści

* Dr hab., prof. UR, Uniwersytet Rzeszowski, Kolegium Nauk Humanistycznych, Instytut Polonistyki i Dziennikarstwa, ul. Rejtana 16c, 35-959 Rzeszów, e.mazur@univ.rzeszow.pl

1 A. Zagajewski, Ziemia ognista, Wydawnictwo a5, Poznań 1994, dalej: Zo; A. Zagajewski, Jechać do Lwowa i inne wiersze, Fundacja Zeszytów Literackich, Warszawa 2009, dalej: JL; cyfra po skrócie oznacza numer strony. 
Wschód (2014)². Rzecz jasna, pojawią się także odwołania do innych utworów i eseistyki obydwu pisarzy. Interesujące wydają się sposoby ukazywania przestrzeni w literaturze polskiej ostatnich dekad, jako epoce cechującej się nomadyzmem, jak też podejście twórców do problemu różnic między Wschodem a Zachodem. Przywoływane tutaj utwory są również okazją do mówienia o procesach migracyjnych i wielokulturowości w edukacji polonistycznej.

Badaniem przestrzeni i miejsca w teorii i praktyce literackiej zajmuje się geopoetyka. Jej domeną jest topografia, czyli zapis miejsc ${ }^{3}$. Przestrzeń nie jest więc traktowana wyłącznie jako kategoria wewnątrztekstowa. Przestrzenie i miejsca kształtują tożsamość jednostkową oraz zbiorową, są związane z refleksją egzystencjalną (przeszłością i czasem teraźniejszym), natomiast za sprawą kategorii doświadczenia również z refleksją (auto)biograficzną i antropologiczną. Miejsce w kulturze jest przestrzenne, funkcjonuje dzięki zbiorowemu wyobrażeniu jako przestrzeń identyfikacji czy zakorzenienia, a niekiedy obcości. Chociaż miejsce jest konkretną przestrzenią, nie zawsze jest ona całkowicie uchwytna, mianowicie w literaturze łączy się z kreacją ${ }^{4}$. Dziennik okrętowy Stasiuka rozpoczyna monolog:

Oczywiście, geografia nie jest tak ważna, jak wyobraźnia, choćby z tego względu, że częściej jest pułapką niż schronieniem. Niemniej jednak te dwie dziedziny, tak od siebie odległe, są powiązane ze sobą węzłem silniejszym niż szaleństwo i rozsądek razem wzięte. Chociażby z tego względu, że szlachetniejsza forma rojenia na jawie zawsze za swój przedmiot bierze przestrzeń ${ }^{5}$.

Geografia literacka traktowana jest jako doświadczenie kulturowe mające wpływ na konstruowanie miejsc i przestrzeni związanych z problematyką tożsamości czy pamięci.

Z kolei zainteresowanie organizacją procesu dydaktycznego, obejmujące analizy i interpretacje wybranych do analiz utworów literatury współczesnej, skłania do przyjrzenia się obowiązującym dokumentom programowym. Mianowicie, w obowiązującej w szkołach ponadgimnazjalnych podstawie programowej poezja

2 A. Stasiuk, Miejsce, w: Opowieści galicyjskie, Wydawnictwo Znak, Kraków 1995, dalej: M, Og; A. Stasiuk, Wschód, Wydawnictwo Czarne, Wołowiec 2014; dalej: W.

3 Zob. E. Rybicka, Geopoetyka. Przestrzeń i miejsce we współczesnych teoriach i praktykach literackich, Universitas, Kraków 2014; A. Kronenberg, Geopoetyka. Związi literatury i środowiska, Wydawnictwo Ut, Łódź 2015.

4 A. Kunce, Miejsce i rytm. O doświadczaniu miejsc w kulturze, w: Genius loci. Studia o człowieku i przestrzeni, red. Z. Kadłubek, Wydawnictwo Fa-art, Katowice 2007, 95-96.

5 A. Stasiuk, Dziennik okrętowy, w: J. Andruchowycz, A. Stasiuk, Moja Europa. Dwa eseje o Europie zwanej Środkowa, Wydawnictwo Czarne, Wołowiec 2000, s. 77; dalej: Dzo, ME. 
Zagajewskiego znajduje się w kanonie 6 . Autor Jechać do Lwowa istnieje obok takich twórców, jak Ewa Lipska i Stanisław Barańczak. W podstawie do języka polskiego dla szkół ponadpodstawowych niestety nie ma poezji Lipskiej i Zagajewskiego. Na liście znaleźli się natomiast: Marcin Świetlicki, Jan Polkowski i Wojciech Wencel $^{7}$. Z kolei prozy Stasiuka, w świetle rozporządzenia obowiązującego w szkołach ponadgimnazjalnych, wśród tytułów kanonicznych wprawdzie nie umieszczono, natomiast ogólne sformułowanie: „wybrana powieść lub zbiór opowiadań z XX lub XXI wieku”8 może - w miarę możliwości czasowych - pozwolić na analizę wybranego utworu autora Murów Hebronu. Natomiast w nowej podstawie w kanonie zakresu podstawowego znalazło się Miejsce (z tomu Opowieści galicyjskie), poza tym jako lektury uzupełniające mogą być omawiane utwory spośród podanych w rozporządzeniu lub ,inne utwory literackie wybrane przez nauczyciela”.

Prawdą jest, że musi upłynąć sporo czasu, aby twórczość zaliczana do najnowszej znalazła stałe miejsce w kanonie, jednak szkoda, że zmiany bywają motywowane również względami pozaartystycznymi. W obowiązującym w szkołach średnich od roku szkolnego 2019/2020 rozporządzeniu znalazł się natomiast zapis następujący:

Podstawa programowa kładzie duży nacisk na zapoznawanie uczniów z literaturą współczesną, dlatego też materiał literacki, poczynając od dzieł literatury starożytnej aż do literatury wojny i okupacji oraz utworów tematycznie z nią związanych musi zostać zrealizowany w klasach I-III. Klasa IV liceum ogólnokształcącego oraz IV i V technikum w całości przeznaczone są na czytanie utworów literatury po 1945 r. oraz kształcenie i rozwijanie refleksji o ich związkach z tradycją literacką i kulturową ${ }^{10}$.

Ponadto $\mathrm{z}$ analiz dokumentów programowych wynika, że podczas interpretacji literatury uczeń powinien dostrzegać w utworach ponadczasowe zagadnienia egzystencjalne, w tym poczucie wspólnoty, inność, solidarność; rozumieć czym jest wolność i tolerancja. Dla przyjętych w niniejszych rozważaniach problemów, istotnych w epoce migracji, stanowi to ważny punkt odniesienia.

6 Podstawa programowa przedmiotu język polski. IV etap edukacyjny. Zakres podstawowy, w: Podstawa programowa kształcenia ogólnego, Rozporządzenie Ministra Edukacji Narodowej z dnia 23 grudnia 2008 r., Dz.U. z 2009 r. Nr 4, s. 50.

7 Podstawa programowa kształcenia ogólnego dla czteroletniego liceum ogólnokształcacego i pięcioletniego technikum. Język polski. Zakres podstawowy i rozszerzony, Rozporządzenie Ministra Edukacji Narodowej z dnia 30 stycznia 2018 r., Dz.U. z dnia 2 marca 2018 r., poz. 467, s. 35.

8 Podstawa programowa..., Zakres rozszerzony, s. 50.

9 Podstawa programowa kształcenia ogólnego dla czteroletniego liceum ogólnokształcącego..., s. 36-37.

10 Tamże, s. 39. 


\section{Miasto(a) Zagajewskiego}

Barbara Toruńczyk uznaje wiersze z tomu Jechać do Lwowa za swoisty autoportret artysty, przywołując zdarzenia następujące:

Pochodził z miasta utraconego przez Polskę w wyniku II wojny światowej. Przesiedlony (na Ziemie Odzyskane) wraz z rodzicami zaznał smaku wyobcowania. Pozbawiony poczucia własnej tożsamości, wszędzie trochę nie na miejscu, wykorzeniony. Dojrzewał wśród obcych murów, jako świadek bolesnej, przesłaniającej barwy życia, tęsknoty najbliższych. Wychowywany w kulturze stałych wartości i wiernej pamięci, obserwował u bliskich odruch mityzacji przeszłości, rytuał oblekania jej w legendę. Sam kierował się nienasyconym pragnieniem życia, scalenia ze światem, zakorzenienia w „tu i teraz”, przeniknięcia zagadkowej, codziennie oczernianej rzeczywistości, a od pewnego momentu także opisania jej złożonej natury"1.

Tytułowy wiersz zbioru Jechać do Lwowa jest imaginacyjną podróżą poety do miejsca urodzenia. Jednak z mitologizacją miejsca splata się tutaj poetyka migracji. Osoba mówiąca znajduje się w permanentnej podróży, a Lwów za sprawą pamięci i wspomnień jest pewną obsesją:

Jechać do Lwowa. Z którego dworca jechać do Lwowa, jeżeli nie we śnie, o świcie,

[...]

Zawsze było za dużo Lwowa, nikt nie umiał zrozumieć wszystkich dzielnic, usłyszeć szeptu każdego kamienia, spalonego

przez słońce, [...]

pakować się, zawsze, codziennie

i jechać bez tchu, jechać do Lwowa, przecież

istnieje, spokojny i czysty jak

brzoskwinia. Lwów jest wszędzie.

(Jechać do Lwowa, JL, 35-37)

Stwierdzenie osoby mówiącej: „Lwów jest wszędzie” to podkreślenie uniwersalizmu tego miejsca pamięci, które znajduje się jakby poza czasem, jest jednak traktowane jako matecznik dla poetyckiej wyobraźni ${ }^{12}$. Wiadomo, że poeta świadomie nie doświadczył Lwowa, więc należy je traktować jako doświadczenie genius loci. „Duch miejsca” kształtował poetę i determinował jego wybory. Przypomnijmy, że:

11 B. Toruńczyk, Czytajac Adama Zagajewskiego, w: „I cień i światło...”. O twórczości Adama Zagajewskiego, red. A. Czabanowska-Wróbel, Wydawnictwo a5, Kraków 2015, s. 44-45.

12 Por. R. Gorczyńska, Szkic wieczności, w: „I cień i światło...”, s. 215. 
W doświadczeniu genius loci dokonują się dwie rzeczy: zostaję jakoś szczególnie „ukierunkowany” przez daną przestrzeń oraz świat; miejsce nabiera teraz jakiejś specyficznej "grubości”. Obydwa te zjawiska spotykają się w chwili, w której czuję, że dana przestrzeń „odnosi się” do mnie, nie otacza mnie po prostu, lecz niejako „dotyka”, „wchodzi” we mnie, staje się elementem mojego ciała. Dokonuje się tu osobliwe połączenie snu i jawy, mitu i twardej rzeczywistości ${ }^{13}$.

Świadomość, że Lwów to miejsce bezpowrotnie utracone i permanentne poczucie samotności, a niekiedy wręcz bezdomność poety, potwierdzają również na przykład frazy z wiersza Dom: „Czy pamiętasz jeszcze, czym był dom?/ Dom - kieszeń w płaszczu styczniowej zawiei”; „Domy, domy, gdzie jesteście, pod którym oceanem, w czyim wspomnieniu, pod dachówką którego nieistnienia?/ Gdy wiatr otwierał okna, do pokoi/ wdzierała się sina przyszłość/ i dławiła oddech muślinowych firanek" (Dom, Zo, 41). Dom-topos traktowany w literaturze polskiej po-Mickiewiczowskiej jako ostoja polskości i tradycji duchowej pojawia się tutaj w wersji zaprzeczonej, mianowicie jako zburzony dom-ojczyzna i brak domu oraz poczucie bezdomności w świecie.

W poezji i eseistyce Zagajewskiego znajduje również odzwierciedlenie trauma związana z wychodźstwem i poczucie obcości miejsc innych. Najpierw były Gliwice - „brzydkie, przemysłowe miasto”, w którym osiedliła się rodzina Zagajewskich. W zbiorze esejów Dwa miasta poświęconym miejscu narodzin i dorastania czytamy: „przez wiele lat opowiadano mi o niezwykle pięknym mieście, które moja rodzina musiała opuścić (o Lwowie). [...] Dlatego właśnie - a przynajmniej tak mi się wydaje - stałem się notorycznie bezdomny"14. Kolejne, po Lwowie i Gliwicach, miasta Zagajewskiego to Kraków, następnie Paryż, i wiele odwiedzanych podczas podróży, jak Wenecja, Nowy Jork i inne.

Doświadczenia (e)migracyjne stały się przyczyną wykreowania w poezji Zagajewskiego obcego miasta. Pisaniu o tych „innych” miastach, towarzyszy niekiedy refleksja o oswajaniu obcości lub o przejściowości sytuacji. Poeta mówi, mnożąc obrazy:

Miasta są wolne, o ileż swobodniejsze

niż ludzie. [...]

Miasta jak promy płyną powoli po

stromych wirach dziesięcioleci,

miasta altany w gęstych ogrodach

oddają zwycięzcom place defilad

i cmentarze, cieniste cmentarze.

(Miasta, $J L, 48$ )

13 T. Sławek, Miasto zapomniane przez Boga i ludzi i fragment z Horacego, w: Genius loci..., s. 67.

14 A. Zagajewski, Dwa miasta, Biblioteka Zeszytów Literackich, Oficyna Literacka, Paryż-Kraków 1991, s. 8. 
Poetyka tego wiersza opiera się na tzw. pamięci skojarzeniowej, czyli zestawianiu różnych elementów rzeczywistości, jak budowle, postaci, dzieła sztuki. Pisanie o miejscach łączy się w wierszu Zagajewskiego z pamięcią asocjacyjną, ponieważ poeta przechowuje budzące intymne skojarzenia miejsca we wspomnieniach. Wyobraźnia opierająca się na sferze poznania i odkrywania miejsc, ale także na erudycji i wrażliwości układa się w liryczny dyskurs o czasie i przemijaniu. Poeta „uniwersalizuje temat wygnania, ukazuje nomadyczny wymiar istnienia człowieka, który dzięki stracie odkrywa wartość tego, co utracone”15. Bycie w drodze jest okazją do wspominania i pamięci o zdarzeniach czy miejscach, ale też potwierdza, że poeta również w obcych miastach poszukuje trwałych śladów cywilizacji.

Poetyka migracji rozumiana jest jako dyskurs nadający sens opuszczeniu ojczyzny i pobytowi poza jej granicami ${ }^{16}$. Zagajewski wyjechał z Krakowa do Paryża w 1982 roku, gdy w Polsce trwał stan wojenny. Do wydarzeń z 13 grudnia 1981 roku porównanych do powstańczych zdarzeń z 1863 roku nawiązał następująco:

Obraz ten został w mojej pamięci, chociaż tego samego dnia działo się wiele innych spraw, ważniejszych, bardziej dramatycznych. Dopiero później zrozumiałem, dlaczego tak się stało. Ci myśliwi, w swoich kurtkach, przepasanych płaszczach, zimowych czapkach, wysokich butach, mężczyźni różnych pokoleń, niosący na ramieniu strzelby, przypominali powstańców, byli rozproszoną powstańczą armią. To Powstanie Styczniowe składało broń, kapitulowało przed Grudniem ${ }^{17}$.

Również w wierszu dom pojawia się fraza: „na ścianie wisiał krzywo krzyż/ z przegranego powstania” (Dom, Zo, 41). Jego twórczość nie jest jednak bliska idei literatury zaangażowanej (w przypadku twórców pokolenia Nowej Fali mamy do czynienia raczej z wyjazdami traktowanymi jako sytuacje egzystencjalne, niekoniecznie polityczne). Chociaż dla pokolenia „BruLionu” tom Jechać do Lwowa i zbiór esejów Solidarność i samotność w latach osiemdziesiątych stały się doświadczeniem formacyjnym, to Zagajewski odmawiał żałoby, nie chciał przyjąć roli poety cierpiącego za ojczyznę. Jego twórczość poetycka bliska jest nowoczesnemu klasycyzmowi, dla jej zrozumienia ważne są konteksty filozoficzne i kulturowe ${ }^{18}$.

15 A. Czabanowska-Wróbel, Laudacja Adama Zagajewskiego. Uniwersytet Jagielloński 2012, W: „I cień i światło...”, s. 130.

16 Zob. P. Czapliński, Kontury mobilności, w: Poetyka migracji. Doświadczenie granic w literaturze polskiej przełomu XX i XXI wieku, red. P. Czapliński, R. Makarska, M. Tomczok, Wydawnictwo UŚ, Katowice 2013, s. 16.

17 A. Zagajewski, Solidarność i samotność, Fundacja Zeszytów Literackich, Warszawa 2002, s. 87.

18 Wiersze mówiące o miastach, nawiązujące do sztuki, np. Widok Delft czy Bezdomny Nowy Jork nie są przedmiotem tego szkicu. Zob. E. Mazur, Kilka uwag o pięknie praktycznym (na przykładzie poezji przełomu XX i XXI wieku inspirowanej malarstwem Jana Vermeera van Delft), w: Dyskursy 
Warto jednak podkreślić, że boleśnie odczuwał sowietyzację, pisząc „odebrany mi został łatwy, naturalny niejako dostęp do powszechnej oczywistości prawdy"19, a traumatyczne doświadczenie wygnania rezonujące w jego utworach związane jest z ucieczką rodziny Zagajewskich ze Lwowa w 1945 roku. To ono sprawiło, że poeta tak często podejmuje temat braku zakorzenienia i bycia w drodze.

Poetyce migracji i odczuwanej z tego powodu obcości odpowiada wyznanie:

W Paryżu było mglisto, meteorolodzy

zapowiadali pochmurny, chłodny dzień.

Czułem gniew na siebie, na moje

ciasne, spętane życie.

Sekwana dusiła się w murach nabrzeża.

$[\ldots]$

Mgła wchodziła do ust, do płuc,

jakby powietrze płakało

(Referendum, Zo, 21)

Oczywiście ważne jest to, że Paryż postrzegany jest tutaj niczym miasto-więzienie, jednak istotniejszy jest stan duchowy osoby mówiącej. Przemysław Czapliński zauważa, że poetyka migracji jest obecnie związana z jej autokreacyjnym charakterem:

Być migrantem to w pewnym sensie być skazanym na stwarzanie samego siebie [...]. Migrant jest człowiekiem w ruchu, który na nowo stawia pytania o tożsamość i więź, ustawicznie przepatrując swoją przeszłość i sylabizując swoją przyszłość. Być migrantem to układać opowieść, w której Ja nie ma stabilnego miejsca, a więź z Innymi nie ma trwałych gwarancji ${ }^{20}$.

W poezji Zagajewskiego dość często znajduje odzwierciedlenie poczucie błąkania się po obcym mieście (miastach), które splata się z potrzebą doznawania zachwytu. Sprawia to, że doznania estetyczne mierzą się z wykorzenieniem i obcością, i ostatecznie nie możemy się uwolnić od odczuwania strachu, a niekiedy przerażenia:

Pewien podróżny, który w nic nie wierzył, znalazł się w lecie w obcym mieście.

Kwitły tam lipy i obcość kwitła żarliwie.

$[\ldots]$

pogranicza. Wektory literatury, red. J. Pasterska i Z. Ożóg, Wydawnictwo URz, Rzeszów 2019, s. 632-636.

19 A. Zagajewski, W cudzym pięknie, Wydawnictwo a5, Kraków 1998, s. 11.

20 P. Czapliński, dz. cyt., s. 41-42. 
i dzwony kościołów bijące unisono mogły znaczyć coś więcej niż zwykle znaczyły.

Może dlatego podróżny co chwilę

kładł na piersi, nieufnie sprawdzając czy wciąż ma przy sobie bilet powrotny do miejsc zwyczajnych, w których my mieszkamy.

(Podróżny, Zo, 40)

W obcych miastach przychodzimy na świat, nazywamy je ojczyzną, lecz niedługo wolno nam podziwiać ich mury i wieże.

[...]

W obcych miastach

oglądamy dzieła dawnych mistrzów

i bez zdziwienia rozpoznajemy własne

twarze na starych obrazach.

(Piosenka emigranta, $J L, 16)$.

W tytule jednego z cytowanych powyżej wierszy uwagę zwraca 'piosenka', która niesie na ogół konotacje pozytywne, jednak „mrok wciąż rzuca cień”21 na pojawiające się w poetyckich obrazach światło. Poeta często łączy przeciwieństwa, to poezja dualizmów i zaskakujących skojarzeń. Poczucie obcości łączy się z dyskursem emigracyjnym. Należymy do świata cywilizacji europejskiej, a mimo to jesteśmy ciągle w drodze, a miasta na szlaku tej wędrówki są „obce” ( $W$ obcych miastach i Ciepły deszcz z tomu Płótno (Paryż 1990), Podróżny (Zo).

Bycie w drodze oznacza w poezji autora Jechać do Lwowa nie tylko ucieczkę, lecz także poszukiwanie nowych doświadczeń. Na kanwie takich doświadczeń opiera się sytuacja liryczna wiersza zatytułowanego Wędrowiec:

Wchodzę do poczekalni dworcowej, gdzie

duszne powietrze.

W kieszeni mam książkę,

czyjeś wiersze, ślady natchnienia.

Obok, na ławkach, dwóch włóczęgów i pijak

[...]

Na drugim końcu sali, patrząc gdzieś

w górę, w stronę Italii i nieba,

21 Por. M. Lundquist, Tłumacząc Dzieło Stworzenia, przekł. Z. Kruszyński, w: „I cień i światło...”, s. 59. 
siedzi wytworne starsze małżeństwo.

Zawsze byliśmy podzieleni. [...]

Zatrzymuję się na moment,

niepewny do którego przyłączyć się

cierpienia.

Wreszcie siadam pośrodku,

Czytam. Jestem sam, ale nie samotny.

Wędrowiec, który nie wędruje.

(Wędrowiec, JL, 65).

Poeta operuje paradoksem, potwierdzeniem: ,jestem sam, ale nie samotny” oraz „wędrowiec, który nie wędruje”. Bohatera lirycznego ogranicza zamknięta przestrzeń dworca, jednak tak naprawdę możliwe jest podróżowanie w sferze myśli i uczuće ${ }^{22}$. Jest tutaj wędrowcem, poetą w podróży, a nie emigrantem.

Poza tym, ważnym miastem jest $\mathrm{w}$ poezji Zagajewskiego Kraków, miasto w którym studiował i w którym mieszka. W eseistycznej książce zatytułowanej W cudzym pięknie pierwsze studenckie wrażenia opisał następująco:

Na zewnątrz był komunizm i mróz, a jeśli nie mróz, to dokuczliwa, nieustająca mżawka, która jeszcze bardziej brudziła mury. [...] A jednak miasto było ładne. Lekkość renesansu unosiła je ponad błoto i podłość jesieni, ponad niekończące się sfumato mżawki. [...] Ciężkie jak ołów, lekkie jak renesans. [...]

To była moja pierwsza jesień w tym mieście; chłodna i deszczowa jesień. [...] Podziwiałem to miasto, byłem nim zachwycony, ponieważ znajdowałem tu nie przerwaną przez wojnę ciągłość życia. Był rok 1963, miałem osiemnaście lat ${ }^{23}$.

Obraz zbudowany na zasadzie kontrastu, historia - ale bez patosu - i melancholijna aura Krakowa składają się na osobną poetykę tego miasta. Trzeba też zwrócić uwagą na słowa: „moja pierwsza jesień w tym mieście”, podkreślające samotność poety.

Podobnie, melancholijnie, o tym mieście wypowiada się podmiot liryczny wiersza Widok Krakowa, w którym poeta prowadzi grę z czasem:

Przede mną Kraków, szara dolina.

Plantami, gęstym tunelem, biegnie

dziewczyna na wykład, spóźniona.

$[\ldots]$

22 Por. J. Klejnocki, W obcym mieście. „Sam, ale nie samotny”, w: tenże, Bez utopii? Rzecz o poezji Adama Zagajewskiego, Wydawnictwo Ruta, Wałbrzych 2002, s. 112-113.

23 A. Zagajewski, W cudzym pięknie..., s. 37-38. 
Biegnie szybko, lecz się nie przesuwa, wciąż jest w tym samym miejscu

(Widok Krakowa, JL, 76-77)

Widok Krakowa to obraz miasta utkany ze wspomnień z czasów studiów i sprzed emigracji do Paryża w 1982 roku. Ponownie temat ów pojawi się w tomie Powrót z 2003 roku, gdy po dwudziestoletnim okresie (e)migracji Zagajewski wrócił do Krakowa. Odkrywanie dobrze znanych sprzed lat zakamarków konfrontowane jest $\mathrm{z}$ obrazami współczesności.

Pora na kilka uogólnień. Poezja autora Jechać do Lwowa powinna współtworzyć kanon szkolnej edukacji polonistycznej, ponieważ mówi o istotnych problemach współczesnej cywilizacji. Punktem wyjścia jest często konkret, który stopniowo przechodzi w metaforę i symbol. Twórca pokazuje jednostkę uwikłaną we współczesną historię, stąd Lwów bywa przeciwstawiany miastom obcym. W poezji autora Ziemi ognistej zaobserwować można przy tym kilka odmiennych spojrzeń na miasto: Lwów jako genius loci, obce miasto-moloch i miasto prywatne, czyli Kraków. Wykreowane w poezji Zagajewskiego miejsce znaczące "przechowuje” poeta we wspomnieniach, z kolei obce miasto, jako przestrzeń zamknięta, ukazywana w kontekście egzystencjalnym najczęściej rodzi lęk, a poeta eksponuje w ten sposób poczucie samotności jednostki w wielkim mieście. Sądzić można, że bezpiecznie czuje się $\mathrm{w}$ „renesansowym, dumnym mieście”.

\section{Miejsce(a) Stasiuka}

Proza Stasiuka zasługuje na uwagę, ponieważ odwołuje się do ponadczasowych zagadnień egzystencjalnych, pozwala zrozumieć dzisiejszemu czytelnikowi komunizm, stanowi okazję do dyskusji na temat tego, czym jest wolność i tolerancja, poza tym mówi o przemijaniu.

Oto jak bohater Dziennika okrętowego wspomina swoje lata szkolne i początki podróżowania:

Wczesne lata siedemdziesiąte... tak, wtedy zaczynała się prawdziwa wolność podróżowania. Ojciec odwoził mnie na dworzec PKS Stadion, wsadzał do autobusu i jechałem prosto na wschód, do dziadków, do podlaskiej wsi rozłożonej na wysokiej skarpie nad Bugiem (Dzo, ME, 132).

Oczywiście wyprawy na Podlasie nie odbywały się tylko w poszukiwaniu korzeni, ale także z tej przyczyny, że podróże na Zachód były niemożliwe. Bohater Dziennika... za sprawą synestezji kreśli miasta widziane oczyma wyobraźni, z perspektywy żyjącego za żelazną kurtyną ucznia komunistycznej szkoły: 
Paryż był szarobłękitny. Londyn lekko zielonkawy, Madryt brązowy z oliwkowym odcieniem. Wiedeń chyba czerwony, wpadający w róż. Berlin na pewno bury. W dzieciństwie nie tylko samogłoski mają swoje kolory. Właściwie wszystkie rzeczy, zwłaszcza te nigdy nie widziane, emanują tajemniczym blaskiem (Dzo, ME, 131).

Pisarz często podkreśla w taki sposób różnice między Wschodem a Zachodem, zwracając uwagę, że doświadczenie komunizmu sprawiło, że na Zachodzie postrzegani jesteśmy jako outsiderzy ze Wschodu. W jego pisarstwie interesująca okazuje się jednakże „przemiana prowincjonalizmu z kompleksu w świadomą strategię" 24 .

W Opowieściach galicyjskich Stasiuk także kreuje wizerunek pisarza outsidera, który wybiera ucieczkę z centrum na obrzeża: do Beskidu Niskiego ${ }^{25}$. Peryferyjność nie jest i w tym przypadku kompleksem, prozaik opuszcza centrum i jednocześnie odrzuca „kompleks barbarzyńcy”.

Jednak tereny pogranicza, które mają być ucieczką z wyniszczającego psychikę miasta, nie uzdrawiają. W tym pejzażu żyją ludzie biedni, wyniszczeni przez alkoholizm, zmagający się z utratą pracy. Ich portrety i historie złożyły się na opowieści tworzące cykl ${ }^{27}$, którego akcja rozgrywa się w czasie transformacji ustrojowej. Zmiany historyczne, a wraz z nimi społeczno-obyczajowe wymusiły aktywność adaptacyjną mieszkańców, którzy do tej pory żyli w symbiozie z naturą.

Pisarz antropomorfizuje naturę, zbliżając ją ku człowiekowi, ukazuje ludzkie bytowanie utrwalone w rytuałach codzienności podobnych w swoim trwaniu do porządków natury, kreuje możliwe światy rzeczy z właściwym im cyklem narodzin i rozpadu.

Opowieści o bieszczadzkiej codzienności z końca świata układa w serię obrazów rzeczywistości postrzeganej jako jedność kulturowo-cywilizacyjna powstała z wymieszania wysokich i niskich obiegów, a także jedność porządków natury, wśród których porządek powszedniego ludzkiego istnienia jest tylko jednym $\mathrm{z}$ wielu. W ujęciu Stasiuka nie jest to jedność ani doskonała, ani dążąca do zhierarchizowanej, ustrukturowanej aksjologicznie, doskonałości ${ }^{28}$.

24 E. Dutka, Pytania o Europe „zwana Środkowq" w pisarstwie Andrzeja Stasiuka, w: taż, Próby topograficzne. Miejsca i krajobrazy w literaturze polskiej XX i XXI wieku, Wydawnictwo UŚ, Katowice 2014, s. 212.

25 Zob. P. Czapliński, Mapa, córka nostalgii, w: tenże, Wzniosłe tęsknoty. Nostalgie lat dziewięćdziesiątych, Wydawnictwo Literackie, Kraków 2001, s. 117.

26 P. Czapliński, Barbarzyńca na zagrodzie. Podróż do Niemiec i polska dusza, „Tygodnik Powszechny" 2007, nr 42, s. 24.

27 Opowieści galicyjskie doczekały się adaptacji filmowej: Wino truskawkowe (2008), reż. Dariusz Jabłoński.

28 H. Gosk, Bohater swoich czasów. Postać literacka w powojennej prozie polskiej o tematyce współczesnej, Świat Literacki, Izabelin 2002, s. 142. 
Miejsce nie jest w tym względzie wyjątkiem, jest celową strategią cechującą prozę Stasiuka, Opowieści galicyjskie zbudowane są bowiem na antynomiach: poszukiwanie wewnętrznego ładu i harmonii zderza się z degrengoladą popegeerowskich wsi i wątkami obyczajowymi ${ }^{29}$.

Fabuła opowiadania Miejsce opiera się na zdarzeniach rozgrywających się po 1989 roku przeplatanych zdarzeniami fikcyjnymi, będącymi snuciem opowieści o przeszłości (o cerkwi, ludziach zamieszkujących w przeszłości pogranicze, łemkowszczyźnie, wielokulturowości i historii). Stasiuk pokazuje w ten sposób tradycję i obyczajowość ludową, a przede wszystkim kulturę, która żyła swym własnym życiem, bez świadomości bycia kulturą. Zaznaczyć też trzeba, że przedstawione w opowiadaniu zdarzenia fikcyjne są prawdopodobne, szczególnie te o randze pozaliterackiej, czyli historycznej.

Jak wiadomo, przełom XX i XXI wieku oznacza także zjawisko globalizacji kultury, które jest zagrożeniem dla autentyczności kultury dawnej. Stąd ważną cechą prozy Stasiuka jest nostalgia za światem, który minął. W Opowieściach galicyjskich pisarz dąży do zwięzłości wywodu poprzez ograniczanie refleksji do spostrzeżeń pozornie najprostszych. Jego bohater stwierdza: „miejsca nie można przenieść” $(M, O g, 35)$, pozostaje niezmienne, żyje we wspomnieniach, mimo że:

Bardzo szybko się uwinęli. W dwa miesiące. Pozostał prostokąt szarej, gliniastej ziemi. W lesistym i bezludnym pejzażu ta nagość wygląda jak płatek zdartej skóry. W przyszłym roku, pierwszy raz po dwustu latach, wyrośnie tutaj trawa. Albo raczej pokrzywy - one najprędzej zjawiają się w miejscach porzuconych przez ludzi.

- Co tu było? - zapytał mnie mężczyzna [...]

- Cerkiew - odpowiedziałem

- I co się stało?

- Nic. Zabrali ją do muzeum.

- Całą?

- Całą, ale po kawałku [...]

- Szkoda - powiedział.

- Tak - odmruknąłem. $(M, O g, 29)$

29 Podczas spotkania z Andrzejem Stasiukiem, które odbyło się w Uniwersytecie Rzeszowskim 24 kwietnia 2014 r. w ramach sympozjum, pisarz zapytany czy Opowieści galicyjskie są zbiorem opowiadań, czy powieścią odpowiedział następująco: „Trudno to rozpoznać, bo teksty, które złożyły się na tę książkę, były pisane na początku jako portrety ludzi z prowincji, z upadających PGR-ów i w pewnym momencie się przemieniły w prozę literacką z realizmem psychologicznym [...]. Rzeczywiście, nie bardzo wiadomo, czym jest ta książka. Jest w niej jakaś fabuła, ale czy jest to już powieść, czy jednak wciąż reportaż? Nie wiem. To jest hybryda - jak cała współczesność". Dzikość lektury. Spotkanie z Andrzejem Stasiukiem, w: Miejsca, ludzie, opowieści. O twórczości Andrzeja Stasiuka. Studia i szkice, red. M. Rabizo-Birek, M. Zatorska, D. Niezgoda, Wydawnictwo URz, Biblioteka „Frazy”, Rzeszów 2018, s. 20. 
Zwraca uwagę swoista oszczędność słowa, cechująca kulturę ludową, w której duże znaczenie mają gesty, praktyki sakralne, elementy ikoniczne. Najważniejsze jest jednak tytułowe miejsce, narrator-bohater konstatuje: „Pomyślałem sobie, że mężczyzna, zapewne przez przypadek, sfotografował przestrzeń, w której znajdował się ikonostas. Teraz była opróżniona z kształtów, lecz wypełniało ją światło" $(M, O g, 31)$. To doświadczenie nazwać można fenomenologią „ducha miejsca”. Jak wiadomo, Genius loci to doświadczenie przestrzeni, którą wypełniają rzeczy nieuchwytne i niedostrzegane wcześniej.

Oto zakończenie opowiadania:

Nie jestem miłośnikiem ruin. Ale wizja odnowionej świątyni stojącej pomiędzy innymi domami i sprzętami tak samo wyjętymi z ich czasu i miejsca ma w sobie skazę jednowymiarowości. Badacze owadzich nogów będą się spierać o rutenizację albo latynizację fryzów i przedstawień. Barok będzie szedł o lepsze z bizantyjskością, policzone zostaną proporcje i ktoś ostatecznie ustali typ i czystość bryły. Lecz miejsca nie można przenieść. Miejsce nie ma wymiarów. Jest punktem i nieuchwytną przestrzenią. Dlatego wciąż nie mam pewności, czy rzeczywiście ją zabrano.

Mężczyzna zamknął futerał aparatu.

- A w którym miejscu było wejście? - zapytał.

- Tu. Stoi pan na progu $(M, O g, 35)$

Miejsce to opowieść o przemijaniu i o wsi, która istnieje tylko w pamięci. Oto wymowny fragment opowiadania: „stary człowiek wskazywał miejsca, gdzie stały domy, wymieniał imiona, opowiadał okruchy jakichś zdarzeń” ( $M, O g, 34)$. Pisarz zwraca uwagę na zróżnicowanie etniczne terenów pogranicza, jednak nie przedstawia tego w ujęciu stereotypowym: „swoi - obcy”. Jeśli sygnalizuje takie przeciwstawienie, to ma ono charakter kontekstowy, zależny od konkretnego kontekstu znaczeniowego - historycznego, społecznego i kulturowego ${ }^{30}$. Sygnalizuje, że grupę etniczną Łemków wyróżnia deklarowane poczucie odrębności, w tym określone elementy kultury, jak budownictwo czy strój ${ }^{31}$. Zdaje sobie sprawę, że piękno ziem pogranicza, ale także i symbioza kultur są zagrożone.

„Im obraz dalej sięga w przeszłość, tym jego kolory, kształty i zdarzenia bardziej przypominają alegorie i symbole” $(M, O g, 31)$ - powiada narrator opowieści. Za sprawą metaforyzacji języka zostają przekroczone granice dosłowności i realizmu, ważne jest rozumienie symboliczne, które potwierdza związki prozy Stasiuka z opowiadaniami Brunona Schulza.

30 Zob. Z. Benedyktowicz, Portrety „obcego”. Od stereotypu do symbolu, Wydawnictwo UJ, Kraków 2000, s. 30.

31 Por. R. Reinfuss, Łemkowie jako grupa etnograficzna, „Prace i Materiały Etnograficzne”, t. 7, 1948/1949, s. 71 i nast. 
Fascynację Wschodem i obecność dyskursu o przemijaniu potwierdza także jedna z najnowszych książek Stasiuka powieść hybryda Wschód. Opublikowana w 2014 roku eseizowana proza jest wspomnieniem z podróży po wschodniej Polsce i z wyprawy do Rosji, Mongolii i Chin. Jej fabuła zawiązuje się podobnie jak opowiadanie Miejsce - to również wschodnia Polska w okresie transformacji ustrojowej:

Minionego lata Dżery kupił wyposażenie sklepu z pegeeru. Wszystko: lady, półki, jakieś gablotki i starodawną wagę z szalkami i wskazówką wędrującą za szkiełkiem. Ładowaliśmy ten komunistyczny zabytek na klepisko stuletniej łemkowskiej chałupy[...], cudem przeżyłej we wsi, z której zniknęły wszystkie domy. Przepadło, rozpadło się, poszło z dymem, sześćdziesiąt cztery chałupy. [...] przetrwała jedna i teraz upychaliśmy do jej wnętrza komunistyczne resztki. [...] Ładowaliśmy. Drewno i sklejka były tłuste od dotyku rąk i rzeczy, nasiąknięte zapachami i ciężkie. Życie w nie weszło i zastygło. Warstwy życia: łemkowszczyzna, komunizm i teraz my, spoceni od tego ciężaru (W, 7; 11-12).

Stasiuk sytuuje bohaterów w lokalnych przestrzeniach, posługuje się idiolektami, by uwiarygodnić prezentowany wycinek przestrzeni. Geograficzny wymiar i zakres przestrzeni wyznaczają nazwy miejscowe. Narrator-bohater Wschodu znajduje się w drodze, dzięki temu poznajemy wybrane miejsca, krajobrazy i spotykanych podczas podróży ludzi. Obserwuje przyrodę, najczęściej nieskażoną przez cywilizację.

Wymowny jest na przykład obraz podróży bohatera przez Podkarpacie, towarzyszy mu bowiem słuchanie i śpiew godzinek. „Śpiewam, by przywołać pamięć swoich babek i dziadków" ( $W, 93)$ - powiada. Liturgia godzin zawiera teksty modlitw kanonicznych śpiewanych na jutrznię, prymę, tercję, sekstę, nonę, nieszpory i kompletę. W powieści dzięki intertekstualnej grze znalazły się strofy śpiewane o świcie: „zacznijcie wargi nasze, chwalić pannę świętą...” i w trzeciej godzinie dnia: „tyś krzak Mojżeszów, boskim ogniem gorejąca...”. Pisarza fascynuje ów odchodzący świat, gdy na prostych ludzi „spływał [...] dar poezj” (W, 93-94). W dziele zwracają uwagę zabiegi intertekstualne, w tym aluzje do Księgi Wyjścia: „I matka, i ojciec opuścili swoje wsie w ramach wielkiej wędrówki wyklętych ludów. Zostali wywiedzieni z domu niewoli” (W, 25).

Nietrudno zauważyć, że Stasiuk z nostalgią pisze o czasie przeszłym. Ważne są więc w utworze opisy spotkań z matką żyjącą w świecie, który pisarz uważa za bliski, jednak bezpowrotnie utracony i zamknięty. Jak podkreśla Bernadetta Darska:

Opowieści Stasiuka towarzyszy słowo „schyłek”. [...] Umiejętność zauważania następującego końca wydaje się niewypowiedzianym wprost, istotnym postulatem tej książki. Stasiuk przecież niepokoi się, czy w kontekście przyszłości przetrwa pamięć i czy nie odetniemy się od tego, co było, na tyle mocno, że przestaniemy zauważać 
przeszłość. Pisarz znakomicie niuansuje te kwestie, stawiając siebie w centrum, ale i poddając własne doświadczenia dyskretnej uniwersalizacji”32.

Takie myślenie można śledzić obserwując bohatera w podróży. Stasiuk ukazuje bowiem nomadyczny wymiar istnienia, człowieka w ruchu, który jednak wraca do miejsc ważnych, ale też podróżuje na Wschód w celu przepracowania komunizmu. Z tego względu Wschód poświęcony jest podróży po Rosji, Chinach i Mongolii. Nie jest zatem kontynuacją cyklu utworów o Europie Środkowej (Jadąc do Babadag, 2004, Fado, 2006), lecz opowieścią o peryferyjnych zakątkach kontynentu. Stasiuk odchodzi zresztą od terminu Europa Środkowa pojmowanego jako „wspólnota losu i kultury" (Dzo, ME, 106). Towarzyszy mu jednak obecne we wcześniejszych utworach stereotypowe przeciwstawienie Wschód - Zachód. Mianowicie, Wschód to Słowiańszczyzna, a Zachód to innośćlobcość ${ }^{33}$. Podróż Stasiuka to także podróż w głąb siebie. Przywołajmy fragment rozmowy z matką: „Synku, chciałabym, żebyś na Zachód jeździł, mówi. Mama, jak ja mam na Zachód jeździć? Z tej nadbużańskiej równiny? $\mathrm{Z}$ tych piasków, w które waliły pioruny? $\mathrm{Z}$ tych wądołów ze stojącą zielonkawą wodą?" $(W, 55)$.

Zainteresowanie Wschodem, to czym jest, jak jest rozumiany i na czym polega jego ,inność” w rozmowie z Piotrem Brysaczem tłumaczy Stasiuk następująco:

Bo na Wschodzie w ogóle umysł lepiej działa. Ma więcej miejsca. Tak mi się wydaje. Jednych przeraża ta otchłań, a mnie nastraja medytacyjnie. Step [...] to jest coś w rodzaju zmaterializowanej religii. [...] Tam rzeczywiście jest większa zgoda, by się rozpuścić w tej przestrzeni - nawet jak ona skrywa jedynie pustkę. A może właśnie dlatego ${ }^{34}$.

Stasiuk podróżuje coraz dalej na Wschód, by odnaleźć „,pożywkę dla wyobraźni", by kontemplując przestrzeń rozmyślać o przemijaniu, by podjąć próbę uporania się z demonami przeszłości i pokazać wieloaspektowo uwikłanie Polaków żyjących w PRL-u w komunizm. Rosja „była wszędzie, w radiu, w czarno-białym telewizorze, w gazetach, w atmosferze", ale tak naprawdę nikogo nie interesowała. Pisarz stara się dziś „dotknąć Rosji”, ale - nie w Moskwie i Petersburgu, tylko „na krańcach imperium, gdzie przybyszowi trudniej zamydlić oczy”35. Poza tym, ciąg-

32 B. Darska, „Wschód” Andrzeja Stasiuka, https://kultura.onet.pl/recenzje/wschod-andrzeja-stasiuka-recenzja/q6ty942 (dostęp 16.09.2017).

33 Zob. E. Dutka, dz. cyt., s. 208-209.

34 A. Stasiuk, Rozbić namiot na Gobi, patrzeć jak Bug płynie..., w: Patrząc na Wschód. Przestrzeń, człowiek, mistycyzm, pytał P. Brysacz, Fundacja Sąsiedzi, Białystok 2013, s. 15.

35 Zob. D. Nowacki, Stasiuk węszy na Wschodzie, http://wyborcza.pl/1,75410,16649423,Stasiuk_ weszy_na_Wschodzie__NOWA_KSIAZKA_.html (dostęp 16.09.2017). 
nie go coraz dalej na Wschód, ponieważ: „Rosja była źródłem, ale to Chiny miały stać się falą, która zaleje świat. Dlatego musiałem tam pojechać, żeby zobaczyć, w co zmienia się komunizm, którego byłem dzieckiem” (W, 214).

Ironizuje na temat konsumpcjonizmu, ale ma świadomość, że poddaliśmy się kiczowi i tandecie:

Ten Lewiatan świata zdąża do chwili, gdy z różowego plastiku, z gumy i folii będzie w stanie wyprodukować nasze myśli i sny $(W, 234)$.

Same Chiny ciekawiły mnie umiarkowanie. Były za stare, zbyt skomplikowane, by szczerze się nimi zainteresować. Przerastały mnie pod każdym względem, ale zdradzały mi moją przyszłość. Były najstarsze na świecie i dlatego najlepiej wiedziały, co się stanie $(W, 235)$.

Pamiętamy podobne przeciwstawienie ducha Europy Środkowej „Zmaterializowanemu Zachodowi”:

Być może tak będzie wyglądała przyszłość. Nasze ojczyzny, nasze kraje znikną jako duchowe, kulturowe punkty odniesienia. Zniknie Polska, znikną Włochy, zniknie Francja. Dlaczego nie? Coraz więcej rzeczy znika i coraz więcej pojawia się nowych. Zostanie Fiat, Coca-Cola, Microsoft, Nike i Johny Walker. Potem i Fiat i Ford znikną, zniknie nawet Nokia i nastaną ich przyszłe doskonalsze wcielenia, do których będziemy się modlić, prosząc o pociechę i nadzieję. Bardzo możliwe, że właśnie w ten sposób Zachód nareszcie połączy się ze Wschodem. Bezdomność duchowych emigrantów stanie się na koniec wspólnym domem ${ }^{36}$.

Otóż, coraz trudniej o wybór między kulturą duchową i materialną, wiernością i wygodą, życzliwością i obojętnością. Do tego typu konstatacji potrzebna jest jednak otwarta przestrzeń, a przekraczanie granic jest także symbolem wolności. Poza tym przemieszczanie się w poszukiwaniu nowego, ale i powroty do miejsc znanych, które pod nieobecność zdążyły się zmienić, to cecha charakterystyczna obserwowania świata przez Stasiuka ${ }^{37}$.

W przywoływanych tutaj opisach krajobrazów pochodzących z prozy podróżnej Stasiuka wynika, że narrator jego fabuł umiejscowiony jest zawsze w określonej przestrzeni, która jest miejscem konkretnym, charakteryzowanym topograficznie. Twórca skupia się przy tym na wybranych szczegółach opisywanych miejsc posługując się często synestezją. Pisarz pośrednio mówi też, że tolerancja oznacza poszanowanie poglądów i zachowań innych.

36 A. Stasiuk, Fado, Wydawnictwo Czarne, Wołowiec 2006, s. 96-97.

37 B. Darska, dz. cyt. 


\section{Podsumowanie}

Wybrane utwory Zagajewskiego i Stasiuka pokazują poetę w podróży i pisarza w podróży. Zasadnicze różnice polegają na odmiennym spojrzeniu twórców na przestrzeń. Miejsca Zagajewskiego to zamknięta przestrzeń miasta, natomiast peryferia Stasiuka pokazane są jako przestrzeń otwarta. Kolejne ważne tropy interpretacyjne dotyczą doświadczenia migracji i doświadczenia komunizmu. Mianowicie, doświadczenie migracyjne $\mathrm{w}$ poezji Zagajewskiego powiązane jest $\mathrm{z}$ problematyką wspominania i pamięci oraz wyobcowania, natomiast doświadczenie podróży na Wschód w prozie Stasiuka motywowane jest mierzeniem się z doświadczeniem komunizmu, a jego podróż po wschodniej Polsce jest także nostalgiczną opowieścią o przemijaniu.

Obydwaj twórcy poruszają problemy szczególnie ważne na przełomie XX i XXI wieku, gdy migracja traktowana jest jako doświadczenie generacyjne. Zamiast konkluzji przywołajmy fragment eseju Stefana Symotiuka:

Istnieją „epoki czasu” i „epoki przestrzeni”. [...] W jakiej epoce żyjemy? Sądząc po pazerności wędrowniczej, po tym, że ludzkość poddała się ogromnej lawinie nomadyzmu turystycznego, że przenosi się z miejsca na miejsce, aby gdzieś w symbolicznych okolicach po prostu trochę "pobyć" - żyjemy w epoce przestrzeni. [...] Krzątamy się w panicznym pośpiechu, dążąc do czegoś w sposób przypominający ucieczkę. Nie mamy czasu na kontemplację czasu ${ }^{38}$.

\section{Bibliografia}

Benedyktowicz Zbigniew, Portrety „obcego”. Od stereotypu do symbolu, Wydawnictwo UJ, Kraków 2000.

Czapliński Przemysław, Barbarzyńca na zagrodzie. Podróż do Niemiec i polska du$s z a$, „Tygodnik Powszechny” 2007, nr 42, s. 24.

Czapliński Przemysław, Kontury mobilności, w: Poetyka migracji. Doświadczenie granic w literaturze polskiej przełomu XX i XXI wieku, red. Przemysław Czapliński, Renata Makarska, Marta Tomczok, Wydawnictwo UŚ, Katowice 2013, s. 16.

Czapliński Przemysław, Mapa, córka nostalgii, w: Przemysław Czapliński, Wznioste tęsknoty. Nostalgie lat dziewięćdziesiątych, Wydawnictwo Literackie, Kraków 2001.

Darska Bernadetta, „Wschód” Andrzeja Stasiuka, https://kultura.onet.pl/recenzje/ wschod-andrzeja-stasiuka-recenzja/q6ty942 (dostęp 16.09.2017).

Dutka Elżbieta, Pytania o Europe „zwana Środkową" w pisarstwie Andrzeja Stasiuka, w: Elżbieta Dutka, Próby topograficzne. Miejsca i krajobrazy w literaturze polskiej XX i XXI wieku, Wydawnictwo UŚ, Katowice 2014.

38 S. Symotiuk, Miejsce i czas, w: Genius loci..., s. 120. 
Genius loci. Studia o człowieku i przestrzeni, red. Zbigniew Kadłubek, Wydawnictwo Fa-art, Katowice 2007.

Gosk Hanna, Bohater swoich czasów. Postać literacka w powojennej prozie polskiej o tematyce współczesnej, Świat Literacki, Izabelin 2002.

Klejnocki Jarosław, W obcym mieście. „Sam, ale nie samotny”, w: Jarosław Klejnocki, Bez utopii? Rzecz o poezji Adama Zagajewskiego, Wydawnictwo Ruta, Wałbrzych 2002.

Kronenberg Anna, Geopoetyka. Związki literatury i środowiska, Wydawnictwo UŁ, Łódź 2015.

„I cień i światło...”. O twórczości Adama Zagajewskiego, red. Anna Czabanowska-Wróbel, Wydawnictwo a5, Kraków 2015.

Mazur Elżbieta, Kilka uwag o pięknie praktycznym (na przykładzie poezji przełomu XX i XXI wieku inspirowanej malarstwem Jana Vermeera van Delft), w: Dyskursy pogranicza. Wektory literatury, red. Jolanta Pasterska, Zenon Ożóg, Wydawnictwo URz, Rzeszów 2019.

Miejsca, ludzie, opowieści. O twórczości Andrzeja Stasiuka. Studia i szkice, red. Magdalena Rabizo-Birek, Matylda Zatorska, Damian Niezgoda, Wydawnictwo URz, Biblioteka „Frazy”, Rzeszów 2018.

Nowacki Dariusz, Stasiuk węszy na Wschodzie, http://wyborcza.pl/1,75410,16649423, Stasiuk_weszy_na_Wschodzie__NOWA_KSIAZKA_.html (dostęp 16.09.2017).

Podstawa programowa kształcenia ogólnego dla czteroletniego liceum ogólnoksztatcacego i pięcioletniego technikum. Język polski. Zakres podstawowy i rozszerzony, Rozporządzenie Ministra Edukacji Narodowej z dnia 30 stycznia 2018 r., Dz.U. z dnia 2 marca 2018 r., poz. 467.

Podstawa programowa przedmiotu język polski. IV etap edukacyjny. Zakres podstawowy i rozszerzony, w: Podstawa programowa kształcenia ogólnego, Rozporządzenie Ministra Edukacji Narodowej z dnia 23 grudnia 2008 r., Dz.U. z 2009 r. $\mathrm{Nr} 4$.

Reinfuss Roman, Łemkowie jako grupa etnograficzna, „Prace i Materiały Etnograficzne”, 1948/1949, t. 7, s. 71 i nast.

Rybicka Elżbieta, Geopoetyka. Przestrzeń i miejsce we współczesnych teoriach i praktykach literackich, Universitas, Kraków 2014.

Stasiuk Andrzej, Dziennik okrętowy, w: Jurij Andruchowycz, Andrzej Stasiuk, Moja Europa. Dwa eseje o Europie zwanej Środkowa, Wydawnictwo Czarne, Wołowiec 2000, s. 77.

Stasiuk Andrzej, Fado, Wydawnictwo Czarne, Wołowiec 2006.

Stasiuk Andrzej, Opowieści galicyjskie, Wydawnictwo Znak, Kraków 1995.

Stasiuk Andrzej, Rozbić namiot na Gobi, patrzeć jak Bug płynie..., w: Patrzac na Wschód. Przestrzeń, człowiek, mistycyzm, pytał Piotr Brysacz, Fundacja Sąsiedzi, Białystok 2013.

Stasiuk Andrzej, Wschód, Wydawnictwo Czarne, Wołowiec 2014. 
Zagajewski Adam, Dwa miasta, Biblioteka Zeszytów Literackich, Oficyna Literacka, Paryż-Kraków 1991.

Zagajewski Adam, Jechać do Lwowa i inne wiersze, Fundacja Zeszytów Literackich, Warszawa 2009.

Zagajewski Adam, Solidarność i samotność, Fundacja Zeszytów Literackich, Warszawa 2002.

Zagajewski Adam, W cudzym pięknie, Wydawnictwo a5, Kraków 1998.

Zagajewski Adam, Ziemia ognista, Wydawnictwo a5, Poznań 1994.

\section{Literackie podróże, czyli o przestrzeni i miejscu w literaturze polskiej przełomu XX i XXI wieku (na przykładzie poezji Adama Zagajewskiego i prozy Andrzeja Stasiuka)}

Streszczenie

Artykuł dotyczy problemów tożsamości, poetyki miejsca i migracji oraz podróży w poezji Adama Zagajewskiego z tomów Jechać do Lwowa (Londyn 1985) i Ziemia ognista (Poznań 1994) oraz w prozie Andrzeja Stasiuka na przykładzie opowiadania Miejsce (Opowieści galicyjskie, Kraków 1995) i powieści Wschód (Wołowiec 2014). Autorka, odwołując się do wybranych tekstów obydwu twórców, prezentuje sposoby ukazywania przestrzeni w literaturze polskiej przełomu XX i XXI wieku naznaczonej doświadczeniem migracji i komunizmu. Szkic analityczno-interpretacyjny zawiera także uwagi związane $\mathrm{z}$ organizacją procesu dydaktycznego, ponieważ omawiane tutaj utwory mogą być inspiracją do mówienia o procesach migracyjnych i wielokulturowości na lekcjach języka polskiego w szkole średniej.

Słowa kluczowe: poetyka miejsca, przestrzeń w literaturze, podróż, migracja, tożsamość, komunizm 


\section{Literary travels: about space and place in Polish literature of the late $20^{\text {th }}$ and early $21^{\text {st }}$ centuries (as seen in the poetry of Adam Zagajewski and the prose of Andrzej Stasiuk)}

Summary

The article deals with the problems of identity, poetics of place, migration and travel in Adam Zagajewski's poetry, in the volumes: Going to Lvov (London 1985) and The Land of Fire (Poznan 1994); as well as in Andrzej Stasiuk's prose: the short story Place (Tales of Galicia, Kraków 1995) and the novel The East (Wołowiec 2014). The author, in invoking selected texts by the above artists, presents ways of portraying space in Polish literature of the late $20^{\text {th }}$ and early $21^{\text {st }}$ centuries, marked by the experiences of migration and communism. This analytical and interpretative study also includes remarks concerning the organisation of the teaching process, as the works discussed here may be used as inspiration for discussions related to migration processes and multiculturalism during Polish language lessons at high school levels.

Keywords: poetics of place, space in literature, travel, migration, identity, communism

Elżbieta Mazur, dr hab., prof. UR - literaturoznawczyni, dydaktyk literatury, pracuje w Instytucie Polonistyki i Dziennikarstwa Uniwersytetu Rzeszowskiego; zainteresowania badawcze: poezja XX i XXI wieku, ekfrazy, podróżopisarstwo, teksty kultury w edukacji polonistycznej, glottodydaktyka; autorka książek: „Rozpoznania”. O twórczości poetyckiej Emila Granata (2001), Oswajanie nowoczesności. Poezja i krytyka Zbigniewa Bieńkowskiego (2015) oraz kilkudziesięciu artykułów i recenzji; redaktorka i współredaktorka czterech tomów zbiorowych, m.in.: Tradycje literatury polskiej XX wieku. Rozprawy i szkice (2010), Literatura współczesna w edukacji polonistycznej, t. I, Analizy i (re)interpretacje (2017). 